物質は使用しない人ほうが良いようです。

また連続的な線量変化のため補正物質の作製が困難に なります。われわれはアクリルによる補正で何んとか目 的とする補正が出来ましたので報告します。

\section{5. 放射線治療における照射部位の再現のための一考案}

久留米大学病院 治療センター 答 原 亭・梅㱦 典良 中嶋 法忠・高 本 浩

[目的]

放射線治療の印は放射線治療以前の閣題で有り，その ため各病院で各自違った方法で行なっている．当放射線 治療センターの経験から次のような方法で行なうと良い と思われる。

[方法, 結果]

今まで治療部位の再確認はすのさしで測定した印の位 置を図譜したカルテを見ていましたがてれらの代わりに マークと同時汇等間隔（5ミリ単位が良いと思う）で張 りめぐらした網の目模様をポラロイドカメラ（即時に写 真の出来が判るため) で撮影し，カルテにはさみ込み必 要な時はそれを見るととにより正確な位置が確梽される.

\section{6. テレコバルトの二次電子濾過板について}

久留米大学医学部付属病院放射線治療センター

梅崎 典良・中嶋 法忠・䇺 原 亭 久留米大学医学部付属病院，中央放射線部 中野 英雄

治療用放射線照射装置は医療法で適当な二次電子濾過 板をつけるよう規定されている。

一般にはカドミウム板が使用され，不透明であるため 照射野を合せられない不便がある。

二次電子濾過板として透明なガラス，アクリル板等が 使用出来ないか子考元, カドミウム板, ガラス板,アク りル板等を二次電子滤過板として使用したときの皮膚面 線量を自作シャロウチェンバーで測定し，比較した結果 ガラス板はカドミウム板に比し大差はなく二次電子濾過 板として使用出来百と考え弓れる。

なお，カドミウム板にはちの巣状に穴をあけたフィル ターとガラス板を併用した場合のフィルタ効果は特に良 い結果であった。

\section{$\diamond$ 関東・東京部会}

日.時 昭和 48 年 10 月 20 日，21日

場 所 山梨県々民会館小ホール

研究発表抄録
1. 超高感度增感紙の使用経験特に，ポータブル撮影に วいて

川鉄干葉病院

○青 木 正・横井 正藏

铇 田 修・佐久間信子

千葉大放技校

田中 仁:高崎 克产

ポータプルX線装置は病室撮影や術中のコントロール には不可欠のものである.しかし装置の出力が小さく， 条件によっては撮影不能の経験も少なくはない。今回は 千大田中らにより第32回放技会で紹介された新タイプの 増感紙 New SS を用いて上記の欠点を補い，かう患者 ・術者の被曝量の軽減がごの程度になるかを測定し，日 常の使用経験と合わせて発表した.

測定方法としてはフィルム法の他, TLD 素子(KYOK KO TLD Reader 1300)を用いた。濃度計はさくら PD -8 型光電濃度計, 装置は日立シリウス 70 型装置である. 上述の New SS はF・S 亿対する感度比が 5.6 5.7（50 $\mathrm{kVp} \sim 80 \mathrm{kVp}$ ）である，さらら高感度フィルムを使用す ると被曝量が軽減される。すなわち増感紙 New SS とフ イルムコダック RP/R を組合わせると約 $1 / 10$ 上下とな る.

\section{2. $X$ 線㝍真のカラー化について}

関東聥信病院放射線科（部長，吉村克俊） ○金場、敏憲・小林 正敏

[目的】 X線写真のカラー化につれては，一般的に次 のように分けることができる.

1つは，X線撮影の段階でカラー増感紙およびカラー フィルムを使って行なう方法と，むう1つは, 通常の白 黒X線写真を 2 次的にカラーX線写真にする方法である. 今回我々の行なった方法は, 後者の方法であるが, 単 にカラー化するだけでなく，Subtraction，或いは，Harmonijation 处理して，より診断的意義を高めるてとを目 的とした。

〔結果】.Electro Subtraction Unitを使って行なうX 線写真をカラー化する方法は，単にオリジナルに色をつ けるだけでなく, Subtraction 又は, Harmonization 等の 処理を行なっで，子り現出能を高めた上でカラー化を行 なうことができX線写真のカラー化へのアプローチの 1 つとして意義があると思う.

\section{3. 最近の90秒フィルムの諸特性}

帝京大学病院放射線科

○宮村 順二・北野 喜文

〔目的】現在市販されているフィルムの中から，7種 